\title{
DOI: 10.38136/jgon.785485
}

\section{The Case Of Isolated Appendiceal Endometriosis Mimicking Appendicitis}

\section{Apandisiti Taklit Eden İzole Apendikal Endometriozis Olgusu}

\author{
Murat ULUDAG \\ Mustafa DONMEZ \\ Feray AYDIN \\ Murat OZKIRLI
}

(1) Orcid ID:0000-0001-6356-7563

(1) Orcid ID:0000-0003-2598-7019

(1) Orcid ID:0000-0003-2847-4780

(1) Orcid ID:0000-0003-4670-7637

\section{${ }^{1}$ Department of General Surgery, Ministry of Health 29 Mayis State Hospital, Ankara, TURKEY}

\section{öz}

Endometriozis, endometrial dokunun uterus dışında yerleşmesidir. Çoğunlukla pelviste görülürken, ekstrapelvik bölgeleri de etkileyebildiği bilinmektedir. Gastrointestinal sistem en sık etkilenen ekstrapelvik bölgedir. Nadiren apendiksi tutarak apandisiti taklit edebilir. Yazımızda, 8 aydır periyodik olarak tekrar eden sağ alt kadran ağrısı olan, çocuk doğurma çağındaki bir kadından bahsedilmektedir. Yapılan abdominal ultrasonografide, apendiksin ucunda duvar kalınlaşması ve etrafında az miktarda sıvı tespit edilmiş olup distal apandisiti düşündürmüştür. Bilgisayarlı tomografide ise apendiksin ucunda yaklaşı $1 \mathrm{~cm}$ 'lik nodüler bir kitle tespit edilmiştir. Hastanın tekrar eden şikayetleri ve tespit edilen bulgular doğrultusunda hastaya apendektomi yapıımış ve histopatolojik incelemesi apendiks endometriozisi olarak raporlanmıştır. Hasta postoperatif dönemde semptomlarından kurtulmuştur. Bu olgu sunumu, sağ alt kadran ağrısına neden olabilen ve apandisiti taklit edebilen izole apendiks endometriozunu vurgulamaktadır.

Anahtar kelimeler: Endometriozis, Apendikal Endometriozis, Apandisit, Sağ Alt Kadran Ağrısı, Apendektomi

\section{INTRODUCTION}

Right lower quadrant (RLQ) pain is a frequent complaint of patients admitting to emergency department and acute appendicitis is the most common symptom-related surgical cause. But, in rare cases it should be noted that, pain can also be caused by appendiceal endometriosis (AE). (1)

Endometriosis is decribed as the pathological proliferation of functioning endometrial tissue outside the uterine cavity. While it is usually detected in pelvic organs near to the uterus, it could also affect the extrapelvic parts of body in rare. Gastrointestinal $(\mathrm{GI})$ tract is the most common location of extrapelvic endo-

\section{ABSTRACT}

Endometriosis is the presence of endometrial tissue outside the uterine cavity. It is mostly seen in the pelvis but can also affect the extrapelvic areas of the body. Gastrointestinal tract is the most frequently affected extrapelvic site but rarely involves the appendix. When it occurs, may mimick appendicitis. We presented a childbearing-age woman suffering from right lower quadrant pain. Her complaint was repeating cyclically for 8 months. Abdominal ultrasound disclosed wall thickening at tip of the appendix and small amount of fluid around it, suggesting distal appendicitis. Computed tomography depicted approximately a $1 \mathrm{~cm}$ nodulary mass on tip of the appendix. Then appendectomy was performed and histopathological examination yielded appendiceal endometriosis. She was recovered well and free of her symptom. This report emphasizes the isolated appendiceal endometriosis, which can cause right lower quadrant pain and mimick appendicitis.

Key words: Endometriosis, Appendiceal Endometriosis, Appendicitis, Right Lower Quadrant Pain, Appendectomy

metriosis with the percentage of $3-37 \%$, and it can be seen in the sigmoid colon, rectum, ileum, appendix and caecum respectively. $(2,3)$

Here, we reported a rare case with a RLQ pain mimicking appendicitis. It was revealed $A E$ in histopathological examination. To our knowledge, scant number of isolated AE case, without pelvic illness, was reported in the literatures.

\section{CASE}

A 36-year-old fertile woman admitted to emergency room complaining of RLQ pain for 1 day. She had no genitourinary, gastrointestinal or gynecological symptoms. She reported that 
she was actively menstruating and the pain was cyclically present for 8 months in association with menstruation. She stated that she was presented to hospital several times for the same complaint, was observed for a while with the suspicion of acute appendicitis and than she was discharged from hospital when her symptom was healed. On her medical history, she noticed that she had 2 children with vaginal delivery, had an hemoroidectomy opeation and had been treated for iron defficiency anemia in the past. She did not use alcohol, tobacco and there was no family history of malignancy.

Except tenderness in Mc Burney's point, physical examination was unremarkable with normal vital signs. Blood investigation yielded anemia, low white blood cell count and a normal C-reactive protein level. Pregnancy was excluded with a negative serum $\beta$-hCG. US pointed wall thickening on tip of the appendix and small amount of localized fluid around it, suspected for a distal appandicitis and suggested a computed tomography (CT) examination. CT examination revealed a nodulary mass on distal part of the appendix without any evidence of inflammation.

Although, after about 12 hours of follow-up, her symptom was improved and the diagnosis of acute appendicitis was abandoned, elective appendectomy was decided for recurrent complaint and in order to clarify the mass exhibited on CT examination.

About 20 days later, appendectomy was performed. Intraoperatively a $4-5 \mathrm{~cm}$ length appendix with a $1-1,5 \mathrm{~cm}$ nodule on tip of the appendix was noted without the evidence of inflammation and any other pathological finding. (Figure 1)

Figure 1: Appendectomy specimen seeing the nodular mass on the tip

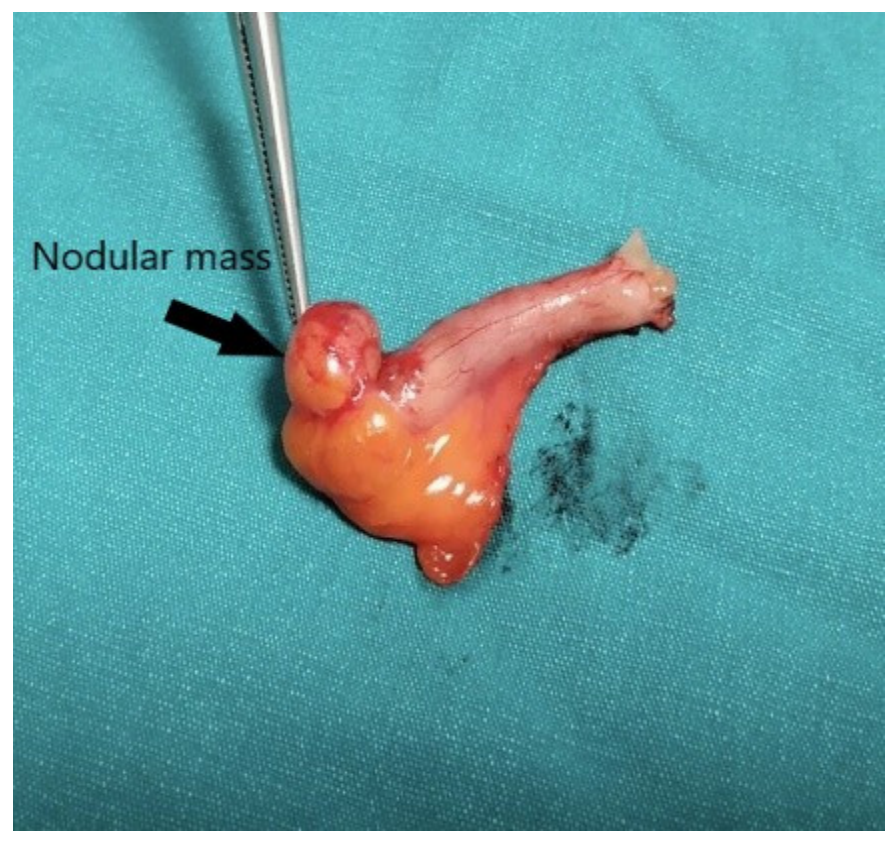

Subsequently, histopathologic examination revealed that the macroscobic analysis of the specimen showed an appendix with $3 \mathrm{~cm}$ of length, $0,8 \mathrm{~cm}$ of diameter and having a $1 \mathrm{~cm}$ nodular mass on tip and the microscobic evaluation demonstrated the presence of endometrial tissue affecting the serozal and muscular layers. (Figure 2) On basis of findings, AE was finally diagnosed.

Figure 2: Histopathological finding; definition of endometrial tissue by stromal and cytoplasmic staining with CD10 indicator

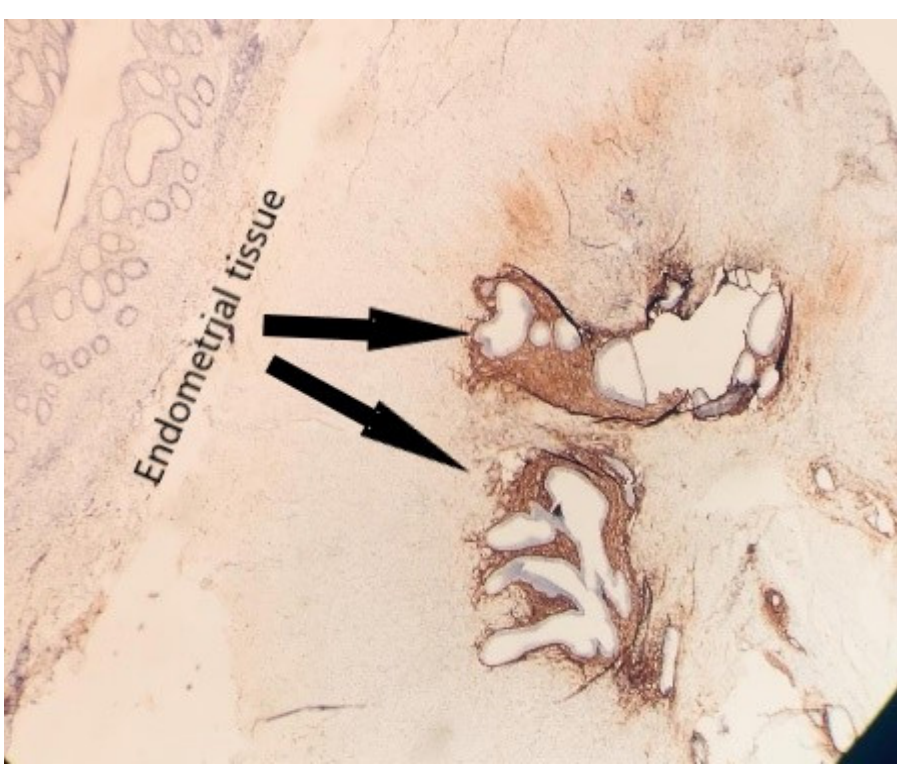

She was discharged postoperative first day, had uneventful recovery and was free of symptoms during the 2 months follow up.

\section{DISCUSSION}

Endometriosis is estimated to affect up to $15 \%$ of women in reproductive age. The clinical features could varies from asymptomatic to pelvic pain, pelvic mass or infertility. $(3,4)$

The clinical presentation of $\mathrm{Gl}$ tract endometriosis depends on the segment of bowel involved and depth of invasion. Most cases are asymptomatic, when present, it can cause abdominal pain, abdominal distention, tenesmus, meteorism, vomitting, diarrhea, constipation, dyschezia, hematochezia etc. And that's why, intestinal endometriosis can be confused lots of disease such as irritable bowel syndrome, inflammatory bowel disease, ischemic colitis, malignancy. Although the magnetic resonance imaging (MRI) has a high sensitivity, it is difficult to perform in every emergency room. Additionally, there are no specific radialogic findings for diagnosis of intestinal endometriosis by ultrasound (US), CT or colonoscopy. Because of these causes above mentioned, there is a challenge to diagnose without sur- 
gery and histopathological evaluation.(2,3)

Extrapelvic endometriosis is generally detected a decade later than pelvic endometriosis at the age of 34-40 years old.(2) This was true for our patient and she was 36 years old.

Although the $\mathrm{AE}$ considered as a rare phenomenon, it has a wide range incidence with $0,05-37 \%$ in the available literatures. This situation is associated with the patient population and the surgical strategies that the surgeons are used to.(5,6). We are agree with this proposal as well. AE may be asymptomatic or present with acute or chronic appendicitis, chronic pelvic pain, intusseption, obstruction, intestinal perforation or bleeding. $(1,4,5)$ Two common appendiceal pathologies that are thought to cause symptoms are mentioned in the study. The initial one is the adhesions and mass effect of the endometriosis and the latter is fibrous obliteration caused by continuous inflammation. (7)

While currently there isn't any pathognomonic clinical or radiologic findings to estimate the appendiceal disease, we may suspect if symptoms are related to menstrual cycles. $(3,7)$ Similarly, our patient's pain was occuring cyclically. Also having a history of infertility and pelvic endometriosis are the other conditions to be suspected. $(1,3,7)$ But our patient had no relevant medical history.

Although US is the most common imaging modality for the evaluation of abdominal pain, it has been reported in different studies that sensitivity and specificity vary to depict entometriosis. CT scan is another imaging modality that is not specific for the diagnosis of endometriosis, but may be useful for evaluating differential diagnoses or complications. $(2,3,4)$ In our case, US was revealed wall thickening on tip of the appendix and small amount of localized fluid around it, CT examination showed a nodulary mass on distal part of the appendix without any evidence of inflammation.

Remorgida and colleagues suggested a system, for staging endometriosis involved bowel, which can be hystologically classified into four groups. Stage 0 , the endometrial tissue affecting the peritoneum and subserosal connective tissue; stage 1 , endometriotic foci are placed in the subserous fat tissue or adjecent to the neurovascular branches, rarely involving the external muscle layer; stage 2, the muscular wall and the Auerbach plexus are deeply infiltrated; stage 3 , the infiltration has reached the submocosal (Meissner) nervous plexus or the mucosa. And in the same study it is mentioned that in the majority of patients $(66.2 \%)$ endometriotic lessions were confined at stage $0 .(8)$ But the endometrial foci was seen both in serozal and muscular layers in our case.

The primarily choice for treatment of $\mathrm{Gl}$ tract endometriosis is surgical excision. Because it is the most efficient and the comprehensive treatment. Treatment is determined by the severity of symptoms, extent and depth of bowel infiltration. The purpose of surgery is to extract all the foci, restore the bowel continuity and function and getting rid off complaints. Thanks to this, the risk of re-intervetional procedures and recurrens of disease will be reduced. But there is still no consensus over the necessity to perform incidental appendectomy for occult $A E$ in women with endometriosis. $(1,2,4,5,7,9,10)$ We performed appendectomy to our patient for recurrent complaint and to make differential diagnosis of mass revealed on CT scan.

In conclusion, isolated appendiceal endometriosis is an uncommon condition that is difficult to diagnose preoperatively and without histopatological evaluation. But it should be kept in mind in differantial diagnosis of RLQ pain, especially if it is recurred in relation to the menstrual cycle.

Acknowledgements: There are no sources of support including sponsorship or sources of material commercially.

Conflict of Interest: The authors have no conflicts of interest to declare.

\section{REFERENCES}

1. Gupta R, Singh AK, Farhat W, Ammar H, Azzaza M, Mizouni A, et al. Appendicular endometriosis: A case report and review of literature. Int J Surg Case Rep 2019; 64: 94-96.

2. Charatsi D, Koukoura O, Ntavela IG, Chintziou F, Gkorila G, Tsagkoulis M, et al. Gastrointestinal and Urinary Tract Endometriosis: A Review on the Commonest Locations of Extrapelvic Endometriosis. Adv Med. 2018 Sep 26;2018:3461209.

3. Hwang BJ, Jafferjee N, Paniz-Mondolfi A, Baer J, Cooke K, Frager D. Nongynecological Endometriosis Presenting as an Acute Abdomen. Emerg Radiol 2012 Oct; 19(5): 463-71.

4. Teiga E, Radosevic A, Sánchez J, Busto M, Aguilar G, Maiques J, et al. A Rare Case of Right Lower Quadrant Pain BJR Case Rep 2018 Oct 31; 5(2): 20170024.

5. Mabrouk M, Raimondo D, Mastronardi M, Raimondo I, Del Forno S, Arena A, et al. Endometriosis of the Appendix: When to Predict and How to Manage-A Multivariate Analysis of 1935 Endometriosis Cases J Minim Invasive Gynecol 2020 Jan; 27(1): 100-106. 
6. Unver N, Coban G, Arıcı DS, Buyukpınarbasıı N, Gu- 9. Adeboye A, Ologun GO, Njoku D, Miner J. Endometricin Z, Malya FÜ, et al. Unusual Histopathological Findings in osis of the Vermiform Appendix Presenting as Acute AppendiciAppendectomy Specimens: A Retrospective Analysis of 2047 tis. Cureus 2019 Oct 1; 11(10): e5816. Cases. Int J Surg Pathol 2019 Apr; 27(2): 142-146.

10. Moulder JK, Siedhoff MT, Melvin KL, Jarvis EG, Hobbs 7. Berker B, Lashay N, Davarpanah R, Marziali M, KA, Garrett J. Risk of Appendiceal Endometriosis Among WoNezhat $\mathrm{CH}$, Nezhat C. Laparoscopic Appendectomy in Pa- men With Deep-Infiltrating Endometriosis Int J Gynaecol Obstet tients With Endometriosis J Minim Invasive Gynecol May-Jun 2017 Nov;139(2):149-154.

2005;12(3):206-9.

8. V Remorgida, N Ragni, S Ferrero, P Anserini, P Torelli, E Fulcheri. The Involvement of the Interstitial Cajal Cells and the Enteric Nervous System in Bowel Endometriosis. Hum Reprod 2005 Jan; 20(1): 264-71. 